\title{
Transparency of Responsible Investment Environment
}

http://doi.org/10.21272/bel.4(4).68-75.2020

Julia Yelnikova, ORCID: https://orcid.org/0000-0002-8478-4716

$\mathrm{PhD}$ in Economics, Senior Scientific Researcher, Sumy State University, Sumy, Ukraine

Abdul Rahman Barhaq, ORCID: https://orcid.org/0000-0001-5521-6368

Deputy Chief Financial Officer, Afghanistan Central Bank, Afghanistan

\begin{abstract}
The study deals with measuring the investment environment transparency for responsible investment, assessing it in Ukraine, and improving it through the rating means in sustainable development. There are ratings, rankings, indices, benchmarks and sustainable development standards as unique markers in responsible investment markets, considering the ESG - criteria for screening companies. The authors prove that ratings are tools for minimizing information asymmetry at the micro and macro levels, which is quite significant, especially in the responsible investment field. Rating is a leading factor in creating a transparent environment for investment decisions and ensuring a favorable investment climate in the world (considering the sustainable development ratings and progress towards sustainable development) and the investment attractiveness of companies (considering ESG - reporting criteria on sustainable development of companies). The authors pay much attention to the world's sustainable development ratings, which incorporate the transparency component of the investment environment. The authors analyze Ukraine's position in these rankings and conclude that its status and investment attractiveness are deteriorating in the international arena, particularly due to insufficient transparency of the investment environment, perception of corporate social responsibility and weak progress towards the Sustainable Development Goals. Structural and dynamic analysis of the signatories and participants of the UN Global Compact network in Ukraine confirm this thesis. Despite the positive dynamics of network members, especially in recent years, their number and composition are unrepresentative towards companies, financial sector institutions, NGOs and government organizations as leaders in the values of sustainable development and social responsibility in Ukraine. Consideration of the European countries' experience embodied in the new EU investment plan, comprising three areas and ten measures aimed at mobilizing 650 billion euros of investment in sustainable development and the investigations made by a supranational organizations network (OECD, UN Development Program, the Sustainability Accounting Standards Board). The Global Reporting Initiative, the International Finance Corporation, the Global Impact Investing Network, and other stakeholders are essential steps in increasing Ukraine's investment environment transparency. Ensuring environment transparency of the responsible investment by introducing methods of ranking companies and countries considering their social responsibility and achievements in the sustainable development field and its goals, standardization of products, techniques and strategies of responsible investment are key priorities of Ukrainian state investment policy.
\end{abstract}

Keywords: Transparency, Investment Environment, Information Asymmetry, Ranking, Sustainable Development, Responsible Investing.

JEL Classification: E22, H54, G24, G14, Q01.

This work is licensed under a Creative Commons Attribution 4.0 International License

Cite as: Yelnikova, Ju., Barhaq, A.R. (2020). Transparency of Responsible Investment Environment. Business Ethics and Leadership, 4(4), 68-75. http://doi.org/10.21272/bel.4(4).68-75.2020.

(C) The Authors, 2020. This article is published with open access at Sumy State University.

\section{Introduction}

The growing trend in the field of responsible investment (RI) in the last decade is accompanied by the growth of information and rating infrastructure and intermediaries in the RI markets, which perform ESG - analysis of data on sustainable development of companies (Vigeo, EIRIS, MSCI, SustainAlytics). Compilation and submission of reports on sustainable development is a key area to reform corporate reporting in the RI processes, the use of Sustainable Development Goals (SDG) as investment targets. A comparison of its distribution among the largest companies in 41 countries confirms the growing trend: in $2011,64 \%$ of the 100 
largest companies in every observed country reported on sustainable development; in $2013-71 \%$; in 2017 $75 \%$ (KPMG, 2011; 2013; 2017). Every year the standards for the preparation of such information are updated (universal International Integrated Reporting Council's, Global Reporting Initiative) (75\% of these companies choose this standard), country-oriented UK's Connected Reporting, a supranational UN Global Compact to the OECD's Guidelines for Multinational Enterprise, a quality-oriented ISO 26000 thematic-oriented Carbon Disclosure Project, focused on materiality, Sustainability Accounting Standards (Working Group on Environmental Auditing (WGEA, 2013). Despite these trends, the transparency and comparability of such information remain extremely low.

\section{Literature Review}

Unlike the approaches of standardization bodies and regulators, which have recently paid attention to the transparency of the RI environment, the theoretical foundations of transparency and information asymmetry in the economy have been studied for a long time. Among foreign scholars, they are represented by K. Arrow (1963), D. Akerlof G. (1970), and Stiglitz J. (1981). The Ukrainian scholars G.V. Kravchuk, V.I. Shevchuk, O.L. Plastun (2013), V.I. Ogienko, O.V. Lunyakov (2012) studied the issue of neutralizing information asymmetry in financial markets. However, the above scientists have not sufficiently represented the information field of the RI markets and their transparency. Some aspects of the investment environment transparency of the RI are the works of such scientists as Windolph S.E. (2011), Chui (Chui J. et al., 2016), Cheng (Cheng, B. et al., 2014) etc. The key method of forming a transparent RI environment and leveling such information asymmetry methods as rating and benchmarking is sustainable development reporting. Such reporting is primarily interdisciplinary and occurs at the intersection of accounting, finance, and management. Mostly foreign scientists, such as Bilbao-Terol A. et al. (2018), Diouf D. (2017), Du Sh. (2017), Lo K. Y. (2017), Miralles - Quiros, M. M. et al. (2017), Mynhardt N. et al. (2017), Rezaee Z. et al. (2017), Sonnenberg D. et al. (2006), Willis A. (2003) represent this scientific field. Simultaneously, the scientific opinion does not contain detailed generalizations regarding the role of sustainable development reporting and ESG criteria in RI rankings and investment decisions, especially in the context of the latest regulatory innovations in this area. Thus, the current study deals with the analysis of approaches to forming a transparent RI environment via rating at the micro and macro levels, considering the ESG - criteria.

\section{Results}

The rating takes a prominent place in financial markets - as an integral element of the global financial architecture (at the level of countries, companies, markets) in traditional and responsible financial markets. As an element that contributes to the investment environment transparency, ratings (rankings, benchmarks, sustainable development indices and RI - hereinafter ratings) allow stakeholders, primarily investors, to investigate the state of investment objects based on the formalized system of criteria. Thus, ratings are considered one of the most effective ways to reduce information asymmetry, which is quite relevant in the RI markets given the lack of field standardization and investment technologies interpretation. Ratings based on the fulfillment of ESG criteria list on a specific methodological basis play a primary role in cases where each investment strategy and product may have a set of unique combinations of profitability, risk and socioenvironmental impact. In general, such ratings define the investment attractiveness of individual companies and their active corporate social position and can be a marker of the world's investment climate. In the latter direction, the ratings indicate the level of investment environment transparency for RI.

Thus, all ratings that organize the set of studied objects according to a particular system of criteria in the sustainable development and RI field can be divided into two groups on the level basis:

$>$ Company ratings.

$>$ World ratings.

Bloomberg ESG Data, Corporate Knights Global 100, DJSI, ISS, MSCI ESG, RepRisk, Sustainalytics, Thomson Reuters ESG Research Data are the most popular among companies' ratings. Thus, these ratings relate primarily to large arrays of companies known for their responsible activities. The MSCI ESG ranking includes more than 6,000 and 350,000 stocks and bonds, Bloomberg ESG Data publishes data for 9,000 companies, and Sustainalytics for 6,500. Typically, these ratings consider the sectoral belonging companies, have a paywall, and are based on ESG - criteria in the activities of rated companies.

However, these ratings have one common feature - they are suitable for characterizing RI companies' investment environment in certain sectors since they rely on sustainable development based on the evaluation criteria. They are not ideal for indicating the country's investment environment at the macroeconomic level. In 
this context, ratings that consider the world's achievements in the field of sustainable development and their progress in achieving the CSB (Table 1) are of particular importance. These lists of ratings with the peculiarities of the criteria and description of the methodology do not claim to be exhaustive but create a general idea of Ukraine's progress towards sustainable development, its goals, and the formation of a sufficient investment pool to finance them, including public investment policy.

Table 1. Ukraine in key country-oriented ratings of sustainable development

\begin{tabular}{|c|c|c|c|c|c|}
\hline \multirow[t]{2}{*}{ Rating } & \multirow[t]{2}{*}{ Organization } & \multirow{2}{*}{$\begin{array}{l}\text { The scale of } \\
\text { the study }\end{array}$} & \multirow{2}{*}{$\begin{array}{c}\text { Criterion } \\
\text { (methodology) }\end{array}$} & \multicolumn{2}{|c|}{ The place of Ukraine } \\
\hline & & & & Value* & Tendency \\
\hline $\begin{array}{c}\text { The Global } \\
\text { Competitiveness } \\
\text { Index }\end{array}$ & $\begin{array}{l}\text { World Economic Forum } \\
\text { (WEF). }\end{array}$ & 141 countries & $\begin{array}{l}\text { Competitiveness is } \\
\text { determined by a set of } \\
\text { institutions, policies and } \\
\text { factors that define the } \\
\text { productivity level }\end{array}$ & 85 (2019) & Negative \\
\hline $\begin{array}{l}\text { Environmental } \\
\text { Performance } \\
\text { Index }\end{array}$ & $\begin{array}{l}\text { Yale Center for Environmental } \\
\text { Law \& Policy and The Center } \\
\text { for International Earth Science } \\
\text { Information Network } \\
\text { (CIESIN) }\end{array}$ & 180 countries & $\begin{array}{l}32 \text { indicators on } 11 \\
\text { topics in two leading } \\
\text { areas - healthy ecology } \\
\text { and ecosystem viability }\end{array}$ & $60(2019)$ & Positive \\
\hline $\begin{array}{c}\text { SDG } \\
\text { achievement } \\
\text { ranking }\end{array}$ & UNO & $\begin{array}{l}193 \text { countries } \\
\text { UNO }\end{array}$ & $\begin{array}{l}\text { The country's overall } \\
\text { progress in reaching } 17 \\
\text { SDGs and their targets } \\
\text { is measured }\end{array}$ & $47(2020)$ & - \\
\hline $\begin{array}{c}\text { Sustainable } \\
\text { Society Index }\end{array}$ & $\begin{array}{l}\text { Sustainable Society } \\
\text { Foundation }\end{array}$ & 154 countries & $\begin{array}{c}\text { Economic, } \\
\text { environmental and } \\
\text { social well-being is } \\
\text { taken into account }\end{array}$ & $\begin{array}{c}130 \text { (economic), } \\
36 \text { (social) } \\
85 \text { (ecological) } \\
(2016) \\
\end{array}$ & Negative \\
\hline $\begin{array}{c}\text { Ease of Doing } \\
\text { Business }\end{array}$ & World Bank банк & 190 & $\begin{array}{c}\text { Quantification of } \\
\text { legislation related to } \\
\text { investment, inflation, } \\
\text { infrastructure, business } \\
\text { income, etc }\end{array}$ & $71(2018)$ & Negative \\
\hline $\begin{array}{l}\text { Index of } \\
\text { Economy } \\
\text { Freedom }\end{array}$ & $\begin{array}{l}\text { Heritage Foundation and The } \\
\text { Wall Street Journal }\end{array}$ & 186 & $\begin{array}{l}\text { Trade, business, } \\
\text { investment, and } \\
\text { property rights are } \\
\text { taken into account }\end{array}$ & $147(2018)$ & Negative \\
\hline
\end{tabular}

Note: The most up-to-date published value available is given

Source: Compiled by the authors according to the Ease of Doing Business (2019), SDG achievement ranking (2020) Sustainable Society Index (2019), Wendling, Z.A., Emerson, J.W., de Sherbinin, A., Esty, D.C., et al. (2020), World Economic Forum, Global Competitiveness Report (2019)

As we can see, Ukraine's position among country-oriented indices is not high enough, and the rating dynamics, except for the Environmental Efficiency Index, is mostly negative. Among these indices, the most suitable in the study of the investment environment transparency are the Global Competitiveness Index of the world and the SDG Achievement Ranking. These two ratings are cross-measurable, in contrast to the others, focusing on one dimension of sustainable development (Environmental Performance Index, Index of Economy Freedom). Besides, the statistics of the Global Competitiveness Index of the world countries and the SDG Achievement Rankings are relevant and date from 2019-2020, in contrast to the Social Sustainable Development Index.

Therefore, these indices are chosen to substantiate the importance of RI investment environment transparency to ensure sustainable development, the world countries' competitiveness, and Ukraine. Ukraine's position in these two ratings is low, indicating a lack of transparency in its investment environment. It is largely caused by the low level of corporate social responsibility perception in Ukraine and the lack of accountability in the sustainable development field. Structural and dynamic analysis of the signatories and participants of the UN Global Compact network in Ukraine is carried out to confirm this thesis (Figs. 1 and 2, Table 2). The organization's membership in this network at the global level is a marker of its high accountability to society, transparency, and commitment to the sustainable development values. 


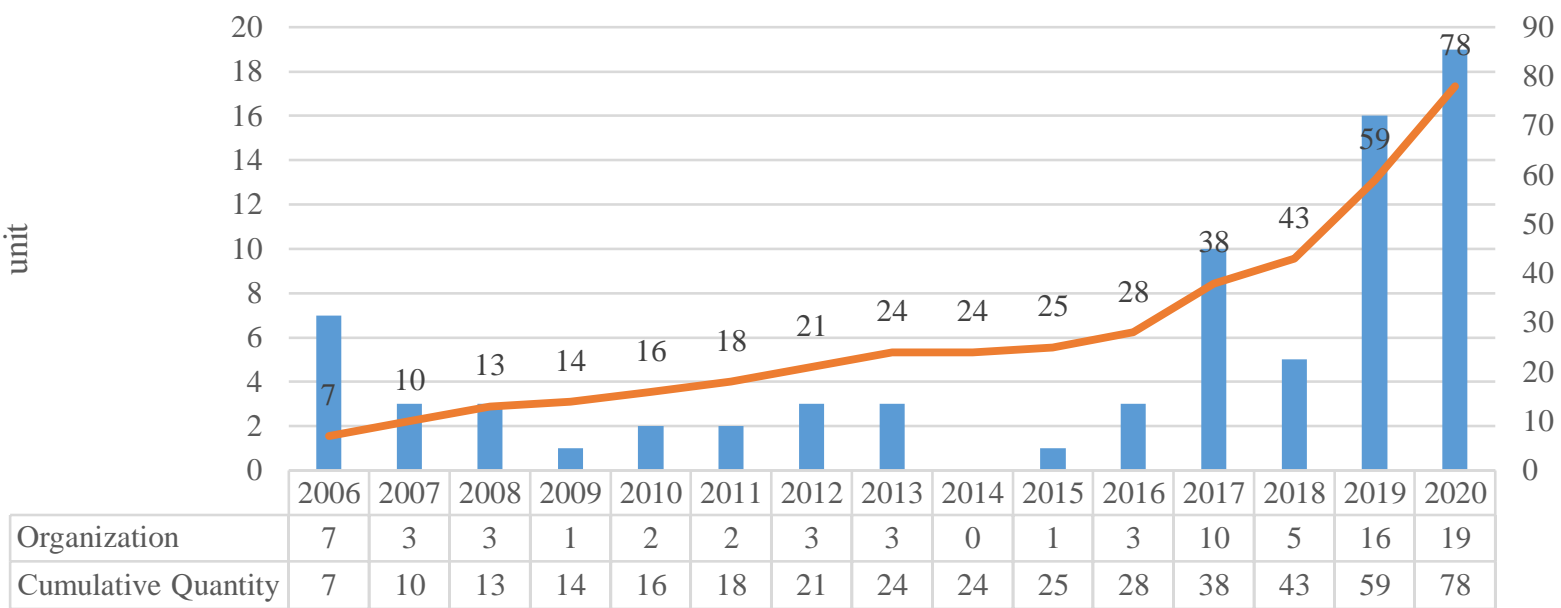

Figure 1. Signatories and participants of the UN General Assembly in Ukraine for 2006-2020

Source: Compiled by the authors according to UN Globalcompact (2020)

Since 2006 (the emergence of the network in Ukraine), the number of sustainable development supporters is growing steadily, and in 2020 it amounted to 78 participants. For comparison, the global network of the agreement has 16,290 participants and signatories. One should note that only in 2019 and 2020, 45\% of its participants joined the Ukrainian network. Despite the positive dynamics of network members, especially in recent years, their number and composition are unrepresentative against the number of reporting companies in Ukraine. The represented companies are pioneers in sustainable development implementation values and its goals and responsible activity, investment, and disclosure of information about them.

The highest transparency level is peculiar for the NGO sector. They account for almost a third $-29.5 \%$ among the surveyed organizations (Table 2). Organizations that provide support services (Support Services) are in the second place. However, according to the UN General Assembly classification, it is a diverse group of organizations (15.4\% of the study population). It includes such companies as Nova Poshta and well-known audit fours such as KPMG and EY. Two types of organizations with equal shares in the study population $6.4 \%$ are in third place. These are institutions of higher education (Academic) and representatives of the IT sector (Software \& Computer Services).

Table 2. Structure of Participants of the UN General Assembly Ukraine in 2020, \%

\begin{tabular}{|l|c|c|}
\hline \multicolumn{1}{|c|}{ Sector } & Organizations & $\%$ \\
\hline Oil \& Gas Producers & 3 & 3,8 \\
\hline Others & 1 & 1,3 \\
\hline Chemicals & 3 & 3,8 \\
\hline Academic & 5 & 6,4 \\
\hline Public Sector Organization & 2 & 2,6 \\
\hline Media & 3 & 3,8 \\
\hline General Industrials & 1 & 1,3 \\
\hline Software \& Computer Services & 5 & 6,4 \\
\hline General Retailers & 1 & 1,3 \\
\hline Agro & 2 & 2,6 \\
\hline Support Services & 12 & 15,4 \\
\hline Food \& Drug Retailers & 1 & 1,3 \\
\hline NGO & 23 & 29,5 \\
\hline Financial Services & 3 & 3,8 \\
\hline Pharmaceuticals \& Biotechnology & 1 & 1,3 \\
\hline Real Estate Investment \& Service & 1 & 1,3 \\
\hline City & 2 & 2,6 \\
\hline Industrial Transportation & 1 & 1,3 \\
\hline Diversified & 1 & 1,3 \\
\hline Automobiles \& Parts & 1 & \\
\hline Beverages & 1 & 1,3 \\
\hline Industrial Metals \& Mining & 1 & \\
\hline Mobile Telecommunications & 2 & 1,3 \\
\hline Electricity & 1 & 1,3 \\
\hline Technology Hardware \& Equipment & 1 & 2,6 \\
\hline Total & 78 & 1,3 \\
\hline Soure: & & \\
\hline
\end{tabular}

Source: Compiled by the authors according to UN Globalcompact (2020) 
In total, these members of the UN General Assembly network in Ukraine represent $57.7 \%$ of Ukrainian organizations. The remaining $42.3 \%$ are representatives of 21 sectors of the national economy. However, onetwo or maximum three companies (Chemicals, Media, Financial Services) represent these sectors. This sectoral distribution is illustrated in Fig. 3.

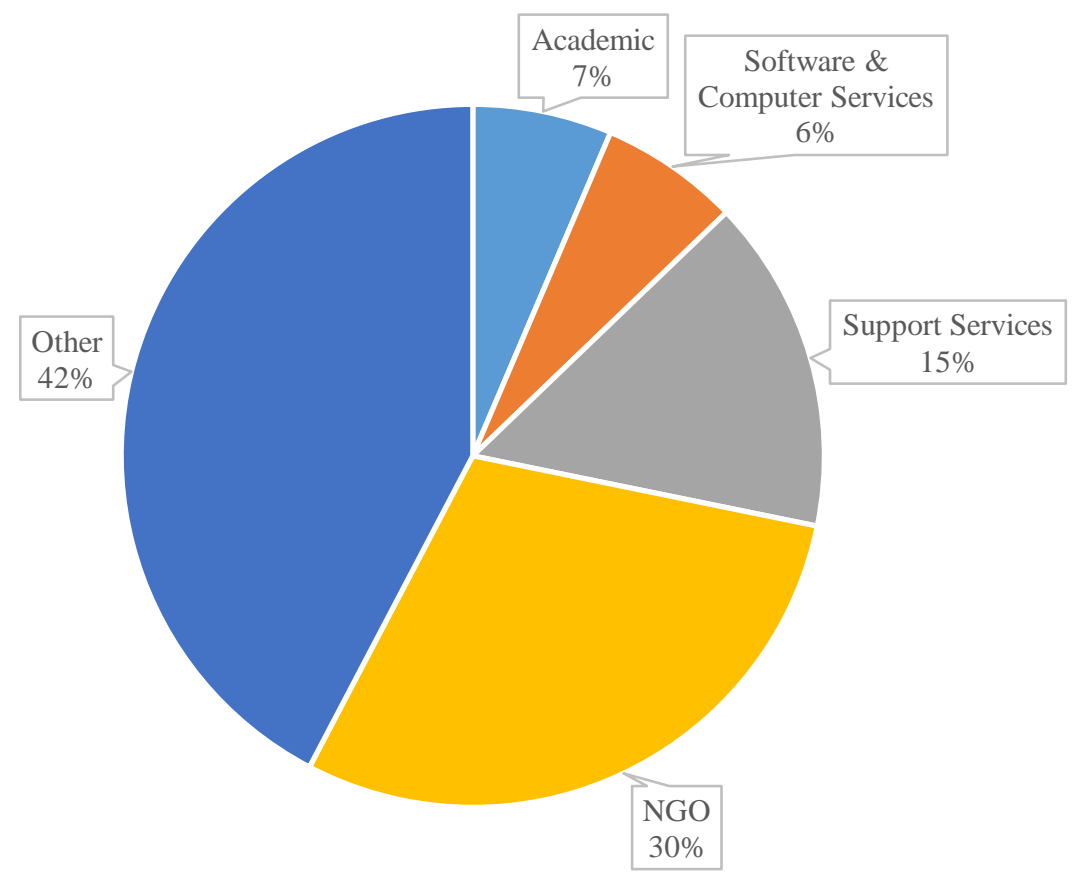

Figure. 3 Sectoral structure of the UN General Assembly network in Ukraine in 2020

Source: Compiled by the authors according to UN Globalcompact (2020)

The structural and dynamic analysis results show that the Ukrainian organizations - signatories of the UN General Assembly form at the initial stage for perception of the sustainable development values and ensuring the transparency of their activities. Thus, the lack of transparency in Ukrainian companies' reporting, its incomparability is a cornerstone leading to low investment environment transparency for investors. Information on the companies' sustainable development is the starting point for RI screening, rating companies, forming industry and national ratings, rankings, and indices on sustainable development (corporate and national level), i.e., is the basis of information support for RI. Therefore, the new state investment policy measures should primarily concern the development of such information and analytical support of RI, information disclosure on sustainable development, social responsibility and progress in achieving SDG at the company level and increasing the transparency of RI investment environment at the macroeconomic level.

Given the growing risks of green washing and SDG-washing, the directions of public investment policy in terms of transparency should be aimed at developing clear conceptual frameworks and standards for RI understanding, managing their risks, measuring their social and environmental effects, construction of benchmarks (ratings, rankings, indices), disclosure of information on RI and their importance to achieve SDG in investor reporting. The OECD, U.N. Development Program, the Sustainability Accounting Standards Board, the Global Reporting Initiative, the International Finance Corporation, the Global Impact Investing Network and other stakeholders united in the global network Impact Management Project (IMP) Structured Network (Horrocks, 2020) share this view. Systematic steps to increase the investment environment transparency for RI and CSR financing are currently implemented in the EU. The adoption of the European Commission's Sustainable Development Financing Action Plan on the recommendations of the High-Level Group of Sustainable Finance Experts in March 2018 is aimed at further comprehensive integration of the EU financial sphere with sustainable development and strengthening the investment environment transparency in the following key areas (Table 3). 
Table 3. Key directions and measures of the European Commission Action Plan for Financing Sustainable Development and Ensuring Transparency of the Investment Environment

\begin{tabular}{|c|c|c|c|}
\hline & $\begin{array}{r}\text { Activities } \\
\end{array}$ & Document & Terms \\
\hline \multirow{5}{*}{ 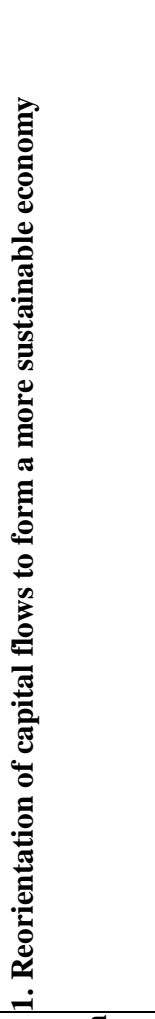 } & $\begin{array}{l}\text { 1.1 Introduction of a clear and } \\
\text { detailed EU Taxonomy in the } \\
\text { sustainable development as a } \\
\text { classification system for responsible } \\
\text { activities }\end{array}$ & $\begin{array}{l}\text { Taxonomy Regulation for climate change mitigation } \\
\text { (Regulation (EU) 2020/852 of the European Parliament } \\
\text { and of the Council of } 18 \text { June } 2020 \text { on the establishment } \\
\text { of a framework to facilitate sustainable investment, and } \\
\text { amending Regulation (EU) 2019/2088) }\end{array}$ & $\begin{array}{l}18.06 .2020 \\
\text { promulgation, } \\
\text { some rules } \\
\text { come into force } \\
\text { on } 01.01 .2022 \\
\text { and } 01.012023\end{array}$ \\
\hline & $\begin{array}{l}\text { 1.2 Establishment of the EU Green } \\
\text { Bond Standard and Labeling of } \\
\text { Green Financial Products }\end{array}$ & $\begin{array}{l}\text { Voluntary EU Green Bond Standard; EU Ecolabel for } \\
\text { retail investment products; Ecolabel framework to } \\
\text { financial products }\end{array}$ & $\begin{array}{l}\text { 3rd quarter } \\
2021\end{array}$ \\
\hline & $\begin{array}{l}\text { 1.3 Promoting investment in } \\
\text { sustainable development in } 4 \text { areas: } \\
\text { sustainable infrastructure, research, } \\
\text { innovation and digitalization; small } \\
\text { and medium business; social } \\
\text { investment and skills }\end{array}$ & $\begin{array}{l}\text { The European Green Deal Investment Plan (EGDIP), also } \\
\text { referred to as Sustainable Europe Investment Plan (SEIP) }\end{array}$ & 2021-2027 \\
\hline & $\begin{array}{l}\text { 1.4 Consideration of the sustainable } \\
\text { development factors in the financial } \\
\text { consulting process }\end{array}$ & $\begin{array}{l}\text { Draft regulation on the obligation of investment firms to } \\
\text { advise clients on social and environmental aspects of } \\
\text { financial products. Amendments to MIFID II and IDD, } \\
\text { and consideration of the such regulators' requirements as } \\
\text { EIOPA and ESMA }\end{array}$ & June 2020 \\
\hline & $\begin{array}{l}1.5 \text { Creating a new category of low- } \\
\text { carbon benchmarks and positive } \\
\text { carbon benchmarks to improve the } \\
\text { carbon footprint information quality }\end{array}$ & $\begin{array}{l}\text { Regulation (EU) } 2019 / 2089 \text { on climate-oriented and Paris- } \\
\text { oriented benchmarks and the sustainable development } \\
\text { information disclosure for benchmarks (Regulation (EU) } \\
2019 / 2089 \text { of the European Parliament and of the Council } \\
\text { of } 27 \text { November } 2019 \text { amending Regulation (EU) } \\
2016 / 1011 \text { as regards EU Climate Transition Benchmarks, } \\
\text { EU Paris-aligned Benchmarks and sustainability-related } \\
\text { disclosures for benchmarks) }\end{array}$ & 27.11.2019 \\
\hline \multirow{3}{*}{ 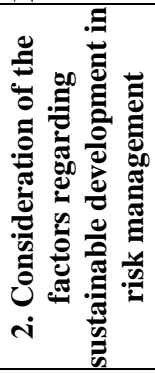 } & $\begin{array}{l}2.1 \text { Integration of sustainable } \\
\text { development factors into credit } \\
\text { ratings and market research }\end{array}$ & $\begin{array}{l}\text { ESMA guidance on disclosure requirements by rating } \\
\text { agencies }\end{array}$ & 2019 \\
\hline & $\begin{array}{l}\text { 2.2 Establishing the responsibilities } \\
\text { of institutional investors and asset } \\
\text { managers to disclose information on } \\
\text { sustainable development }\end{array}$ & $\begin{array}{l}\text { Regulation (EU) 2019/2088 of the European Parliament } \\
\text { and of the Council of } 27 \text { November } 2019 \text { on sustainability- } \\
\text { related disclosures in the financial services sector) }\end{array}$ & $\begin{array}{l}2019, \\
\text { implemented } \\
\text { since } \\
10.03 .2021 \\
\end{array}$ \\
\hline & $\begin{array}{l}2.3 \text { Introduction of a "green support } \\
\text { factor" in the banking and insurance } \\
\text { sectors }\end{array}$ & $\begin{array}{l}\text { European Banking Authority Action Plan on Sustainable } \\
\text { Finance }\end{array}$ & 2019 \\
\hline \multirow{2}{*}{ 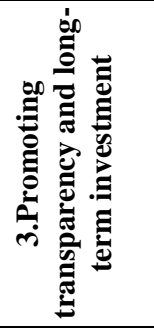 } & $\begin{array}{l}\text { 3.1 Transparency enhancement in } \\
\text { the information disclosure on } \\
\text { sustainable development and } \\
\text { accounting policies }\end{array}$ & $\begin{array}{l}\text { Climate change disclosure guide } \\
\text { Directive 2014/95/EU of the European Parliament and of } \\
\text { the Council of } 22 \text { October } 2014 \text { amending Directive } \\
\text { 2013/34/EU as regards disclosure of non-financial and } \\
\text { diversity information by certain large undertakings and } \\
\text { groups }\end{array}$ & $\begin{array}{c}2019 \\
\text { February } 2020\end{array}$ \\
\hline & $\begin{array}{l}\text { 3.2 Promoting sustainable corporate } \\
\text { governance and reducing short-term } \\
\text { capital markets }\end{array}$ & $\begin{array}{l}\text { Recommendations for strengthening ESG disclosure } \\
\text { criteria and attracting institutional investors (EBA, } \\
\text { EIOPA, ESMA) }\end{array}$ & December 2019 \\
\hline
\end{tabular}

Source: Compiled by the authors according to Sustainable finance renewed strategy action plan and regulatory sources

Under the European Commission's Sustainable Development Financing Action Plan (InvestEU, Juncker Plan, European Fund for Strategic Investments and 13 other public investment policy instruments), the EU budget provides for the mobilization of at least $€ 650$ billion for the RI implementation in the period 2021-2027 (What's next? InvestEU Program (2021-2027). Direction 3 is one of the key areas for promoting this plan: promoting transparency (direct impact on the investment environment transparency for RI). However, in other directions, some measures also relate to directly increasing transparency of the investment environment. They include the introduction of the EU Sustainable Development Taxonomy, creating an EU Standard on Green Bonds and Green Financial Labeling, a new category of low-carbon, the commitment of institutional investors and asset managers to disclose information on sustainable development. These areas are undoubtedly relevant and necessary for implementing the national practice to form an investment environment for Ukraine's RI implementation. 


\section{Conclusions, Discussion and Recommendations}

Consideration of current trends in the RI investment environment transparency requires studying key methods of its provision. Such support acquires a particular context to form the information field for investors' investment decisions on sustainable development projects and RI implementation since a significant level of information asymmetry characterizes this field. Among the rating products aimed at overcoming this information asymmetry, ratings, rankings, indices, benchmarks, and sustainable development standards are observed as special markers in responsible investment markets that consider companies' ESG - screening criteria. The paper considers the main ratings of sustainable development of the world, which incorporate transparency of the investment environment. Analysis of Ukraine's current position in sustainable development ratings shows a deterioration in its status and investment attractiveness in the international arena. The lack of investment environment transparency, the perception of corporate social responsibility and weak progress towards the Sustainable Development Goals both at the company level and at the national level cause it. The results of the structural and dynamic analysis conducted based on the data of the UN General Assembly network confirm the fact that Ukrainian organizations are at the initial stage of perceiving the sustainable development values and ensuring the transparency of their activities. The experience of European countries embodied in the new EU investment plan for 2020-2027 and the work of a supranational organization network are essential steps in increasing the transparency of Ukraine's investment environment. Ensuring transparency of responsible investment environment by introducing rating methods of companies and countries of the world considering their social responsibility and achievements in sustainable development and its goals, standardization of products, methods and strategies of responsible investing are key priorities of Ukrainian state investment policy.

Author Contributions. Conceptualization, Julia Yelnikova; data curation, Abdul Rahman Barhaq; formal analysis, Abdul Rahman Barhaq; funding acquisition, Julia Yelnikova; investigation, Julia Yelnikova; methodology, Julia Yelnikova; project administration, Abdul Rahman Barhaq; resources, Julia Yelnikova; software, JuliaYelnikova; supervision, Julia Yelnikova; validation, Julia Yelnikova; visualization, Abdul Rahman Barhaq; writing - original draft, Abdul Rahman Barhaq; writing - review \& editing, Julia Yelnikova.

Funding. There is no funding for this research.

\section{References}

1. Akerlof, G. (1970). The Market for Lemons: Quality Uncertainty and the Market Mechanism. Quarterly Journal of Economics, 84, 485-500. Available at: https://www.jstor.org/stable/1879431.

2. Arrow, K. (1963). Uncertainty and the Welfare Economics of Medical Care. American Economic Review, 53(5), 941-973. Available at: https://www.jstor.org/stable/1812044.

3. Bilbao-Terol, A. et al. (2018). Multi-criteria analysis of the GRI sustainability reports: an application to Socially Responsible Investment. Journal of the Operational Research Society, 6(10), 1576-1598. doi: 10.1057/s41274-017-0229-0.

4. Cheng, B. et al. (2014). Corporate Social Responsibility and Access to Finance. Strategic management journal, 35(4), 1-23. Available at: https://dash.harvard.edu/bitstream/handle/1/9887635/cheng,ioannou,serafeimCorporate\%20Social\%20Responsibility\%20and\%20Access\%20to\%20Finance.pdf;sequence=1.

5. Cui, J. et al. (2016). Does Corporate Social Responsibility Affect Information Asymmetry? Journal of Business Ethics, 1-24. Available at: https://link.springer.com/article/10.1007/s10551-015-3003-8.

6. Diouf, D. (2017). The quality of sustainability reports and impression management: A stakeholder perspective. Accounting, Auditing \& Accountability Journal, 30(3), 643-667, https://doi.org/10.1108/AAAJ-04-2015-2044.

7. Du, Sh. (2017). The Business Case for Sustainability Reporting: Evidence from Stock Market Reactions. Journal of Public Policy \& Marketing, 36(2), 313-330. https://doi.org/10.1509/jppm.16.112.

8. Ease of Doing Business (2019). Available at: http://www.doingbusiness.org/rankings.

9. Horrocks, P. (2020). Shifting public and private finance towards the Sustainable Development Goals. Available at: https://oecd-development-matters.org/2020/01/09/shifting-public-and-private-financetowards-the-sustainable-development-goals/].

10.Index of Economy Freedom (2019). Available at: http://www.heritage.org/index/ranking.

11.KPMG (2011). The KPMG Survey of Corporate Responsibility Reporting. 2011. Available at: http://www.csr.ee/wp-content/uploads/2016/03/KPMHG-International-Survey-of-CSR-2011.pdf.

12. KPMG (2013). The KPMG Survey of Corporate Responsibility Reporting. 2013. Available at: https://assets.kpmg.com/content/dam/kpmg/pdf/2015/08/kpmg-survey-of-corporate-responsibilityreporting-2013.pdf. 
13.KPMG (2017). The KPMG Survey of Corporate Responsibility Reporting. 2017. Available at: https://assets.kpmg.com/content/dam/kpmg/xx/pdf/2017/10/kpmg-survey-of-corporate-responsibilityreporting-2017.pdf.

14.Lo, K.Y. (2017). The Effect of Environmental, Social, Governance and Sustainability Initiatives on Stock Value - Examining Market Response to Initiatives Undertaken by Listed Companies. Corp. Soc. Responsib. Environ. Mgmt., 24, 606-619. https://doi.org/10.1002/csr.1431.

15.Miralles-Quiros, M.M., et al. (2017). Sustainable Development, Sustainability Leadership and Firm Valuation: Differences across Europe. Bus. Strat. Env., 26, 1014-1028. https://doi.org/10.1002/bse.1964.

16.Mynhardt, H., et al. (2017). Market efficiency of traditional stock market indices and social responsible indices: the role of sustainability reporting. Investment Management and Financial Innovations, 14(2), 94-106. http://dx.doi.org/10.21511/imfi.14(2).2017.09.

17.Rezaee, Z., et al. (2017). Progress Toward Business Sustainability in Asia in the Aftermath of 2015 Hong Kong Stock Exchange Requirements. International Journal of Sustainability Management and Information Technologies, 3(4), 40-45. https://doi.org/10.11648/j.ijsmit.20170304.12.

18.SDG Achievement Ranking (2020). Available at: https://dashboards.sdgindex.org/rankings

19.Sonnenberg, D., et al. (2006). The JSE socially responsible investment index and the state of sustainability reporting in South Africa. Development Southern Africa, 23(2), 305-320. https://doi.org/10.1080/03768350600707942.

20.Stiglitz, J. (1981). Credit Rationing in Markets with Imperfect Information. The American Economic Review, 71(3), 393-410. Available at: https://www.jstor.org/stable/1802787.

21.Sustainable Society Index (2019). Available at: http://www.ssfindex.com/data-all-countries/.

22.Sustainable-finance-renewed-strategy.action-plan $\quad$ (2020). Available https://ec.europa.eu/info/publications/sustainable-finance-renewed-strategy_en\#action-plan.

23.UN Globalcompact (2020). Available at: https://www.unglobalcompact.org/what-isgc/participants/search?page $=2 \&$ search $\% 5$ Bcountries $\% 5 \mathrm{D} \% 5 \mathrm{~B} \% 5 \mathrm{D}=206 \& \operatorname{search} \% 5 \mathrm{Bkeywords} \% 5 \mathrm{D}=\& \mathrm{~s}$ earch\%5Bper_page\%5D=50\&search\%5Bsort_direction\%5D=asc\&search\%5Bsort_field\%5D=\&utf8=\%E $2 \% 9 \mathrm{C} \% 93$.

24.Wendling, Z.A., Emerson, J.W., de Sherbinin, A., Esty, D.C., et al. (2020). 2020 Environmental Performance Index. New Haven, CT: Yale Center for Environmental Law \& Policy. Available at: https://epi.yale.edu/.

25.What's next? The InvestEU Programme (2021-2027). Available at: https://ec.europa.eu/commission/priorities/jobs-growth-and-investment/investment-plan-europe-junckerplan/whats-next-investeu-programme-2021-2027_en.

26.Willis, A. (2003). The Role of the Global Reporting Initiative's Sustainability Reporting Guidelines in the Social Screening of Investments. Journal of Business Ethics, 43(3), 233-237 https://doi.org/10.1023/A:1022958618391.

27.Windolph, S.E. (2011). Assessing Corporate Sustainability Through Ratings: Challenges and Their Causes. JES, 1(1), Article 5. Available at: https://scholarworks.rit.edu/jes/vol1/iss 1/5/.

28.Working Group on Environmental Auditing (WGEA) (2013). Sustainability Reporting: Concepts, Frameworks and the Role of Supreme Audit Institutions. INTOSAI, June. Available at: http://www.environmentalauditing.org/LinkClick.aspx?fileticket=vM4hrHIBd0spercent3D\&tabid=128\&mid=568.

29.World Economic Forum, Global Competitiveness Report (2019). Available at: http://reports.weforum.org/global-competitiveness-report-2019/competitiveness-rankings/.

30.Kravchuk, G.V., Shevchuk, V. I., Plastun, O.L. (2013). Borot'ba z informatsiynoyu asymmentriyeyu yak vazhlyva skladova zabezpechenya finansovoyi bezpeky. Visnyk of Chernihiv State Technological University, 1, 213-220. Available at: https://essuir.sumdu.edu.ua/handle/123456789/52277.

31.Ogiyenko, V.I., Lunyakov, O.V. (2012). Asymetriya informatsiyi v investytsiynykh protsesakh. Actual Problems of Economics, 1(127), 32-334. Available at: https://essuir.sumdu.edu.ua/handle/123456789/57148. 